\title{
Morpho-anatomical characterization of mature embryo-derived callus of rice (Oryza sativa L.) suitable for transformation
}

\author{
R. Bevitori • M. Popielarska-Konieczna • \\ E. M. dos Santos • M. F. Grossi-de-Sá • S. Petrofeza
}

Received: 16 July 2013 / Accepted: 17 September 2013 /Published online: 2 October 2013

(C) Springer-Verlag Wien 2013

\begin{abstract}
The objective of this study was to morphoanatomically characterize embryogenic rice calli during early induction of somatic embryogenesis of three Brazilian rice cultivars. Herein, we explored embryogenic units (EUs) from 2-week-old cut proliferated calli to verify whether they were suitable for Agrobacterium tumefasciens-mediated transformation. Histological analysis and scanning electron microscopy (SEM) were used to analyze these types of calli during early rice callogenesis in the cultivars BRS Primavera, BRS Bonança, and BRS Caiapó. The characteristics of the embryogenic cells were preserved in the EUs, which showed a globular, compact structure that contained tightly packed cells and thus rendered the cells suitable for transformation. The EUs of BRS Caiapó also maintained the characteristics of the nonembryogenic callus, such as an elongated morphology and a lack of cellular organization. In general, the observations of the histological sections corresponded with those of the SEM images. The histological analysis suggested that all cultivars used in these experiments have morphogenic potential. The EUs from proliferated 2-week-old cut calli maintained their embryogenic features. The EUs were subjected to
\end{abstract}

Handling Editor: Pavla Binarova

R. Bevitori $(\bowtie)$

Embrapa Arroz e Feijão, Rodovia GO 462, km 12, 75375-000 Santo

Antônio de Goiás, Goiás, Brazil

e-mail: rosangela.bevitori@embrapa.br

\section{Popielarska-Konieczna}

Department of Plant Cytology and Embryology, Jagiellonian

University, 9 Gronostajowa St., 30-387 Cracow, Poland

E. M. dos Santos · S. Petrofeza

Universidade Federal de Goiás, Goiânia, Goiás 74001-940, Brazil

M. F. Grossi-de-Sá

Embrapa Recursos Genéticos e Biotecnologia, Brasília,

DF 70770-917, Brazil
Agrobacterium-mediated transformation, which exhibited a regeneration frequency of $58 \%$ for transformed hygromycin-resistant cell lines. These results show that EUs from proliferated 2-week-old cut calli are suitable for plant transformation.

Keywords Scanning electron microscopy $\cdot$ SEM $\cdot$ Rice callogenesis $\cdot$ Somatic embryogenesis $\cdot$ Morphogenesis

$\begin{array}{ll}\text { Abbreviations } \\ \text { ECM } & \text { Extracellular matrix } \\ \text { ECMSN } & \text { Extracellular matrix surface network } \\ \text { EUs1 } & \text { Embryogenic units } \\ \text { EUs2 } & \text { Proliferated 2-week-old cut calli } \\ \text { IM } & \text { Induction medium } \\ \text { MS } & \text { Murashige and Skoog } \\ \text { SEM } & \text { Scanning electron microscopy } \\ \text { 2,4-D } & \text { 2,4-Dichlorophenoxyacetic acid }\end{array}$

\section{Introduction}

Apart from its economic significance, rice has become an important plant for genetic and genomic studies. As more of the rice genome sequence and mapping of markers are available, it becomes critical to identify the functions of thousands of new rice genes. Genetic transformation has become an important tool for gene function studies in rice. However, the successful application of this technique requires an efficient tissue culture system because in vitro genetic modification via transformation is largely dependent on the ability of the tissue to produce embryogenic calli and regenerate into whole plants.

In rice, embryogenesis can be initiated from various explants; however, the most commonly used method is based on 
mature embryo culture because these cells are very efficient for callus induction, are consistently available in large quantities, and can be stored for use throughout the year (Hiei and Komari 2008).

Somatic embryogenesis is an in vitro morphogenic response in which embryos are induced from somatic cells, thereby leading to further regeneration of the plants (Williams and Maheswaran 1986). During somatic embryogenesis, changes in explant tissues cause the development of the somatic embryo. In this process, some somatic cells start to divide and become totipotent (Fehér et al. 2002). In general, the process follows three main stages: induction of embryogenic calli, development and maturation of somatic embryos, and conversion of somatic embryos into plants. The induction stage is considered to be of great importance for obtaining well-formed somatic embryos and for the subsequent stages of development, i.e., maturation and conversion into plants.

Pescador et al. (2000) reported that the in vitro plant manipulation system that is used to obtain embryogenic and morphogenic responses is dependent on morphological, genetic, biochemical, cytological, and physiological factors. Morphological evidence of rice somatic embryogenesis initiated by a bipolar structure has been frequently observed (Abe and Futsuhara 1985; Chen et al. 1985; Mendoza and Futsuhara 1992). The callus type is usually evaluated by visual observation during growth in the appropriate medium. Although visual observation offers some judgment in the selection of high-quality calli, it cannot provide information on the cell composition and ultrastructure.

Histology and scanning electron microscopy (SEM) are effective tools in determining the cell composition and structures of different callus types with respect to the potential for regeneration (Narciso and Hattori 2010). Such observations have been performed in rice calli (Nishimura and Maeda 1977; Abe and Futsuhara 1985; Jones and Rost 1989; Mendoza and Futsuhara 1992; Sangduen and Klamsomboon 2001; Vega et al. 2009) for the observation of callus induction, somatic embryogenesis, and plant regeneration, but have not been performed in the early stages of callogenesis, which is an important issue because this is a crucial step in the production of embryogenic calli (Yusoff et al. 2012).

In this study, three types of mature embryo-derived callus were analyzed for the following reasons: first, 2-week-old calli cultured in induction medium were chosen because they can be cut into two, three, or four parts for proliferation for more than 10 days and used for transformation experiments (Hiei and Komari 2008). Additionally, this type of callus has been reported to be competent for Agrobacterium-mediated transformation (Hiei et al. 1994, 1997). Second, we used embryogenic units (EUs) derived from primary callus because this is the most common type used in transformation studies (Hiei et al. 1994; Sallaud et al. 2003; Saika and Toki 2010). Third, proliferated 2-week-old cut calli (EUs2) were analyzed to observe whether they are able to maintain embryogenic callus features. They might be used for direct transformation or proliferation purposes. The identification of embryogenic calli at an early stage may enhance callus development by its proliferation and, thus, accelerate the production of calli suitable for plant transformation.

In this context, we used SEM and histological analysis as tools to identify the morphological features of somatic embryogenesis in the early stage of callogenesis of three Brazilian rice cultivars. The embryogenic ability of the proliferated 2 -week-old cut calli was maintained and useful for Agrobacterium-transformation.

\section{Materials and methods}

Biological material and induction medium

For all experiments, mature seeds of Oryza sativa ssp. japonica rice cultivars BRS Primavera, BRS Bonança, and BRS Caiapó were used for callus induction. They were used because in a previous work they presented 84,72 , and $33 \%$ callus induction, respectively (Bevitori, unpublished). The induction medium (IM) used in this study was the N6 basal medium supplemented with $30 \mathrm{~g} / \mathrm{L}$ maltose, $500 \mathrm{mg} / \mathrm{L}$ proline, $100 \mathrm{mg} / \mathrm{L}$ myoinositol, $6 \mathrm{mM}$ glutamine, $0.1 \mathrm{mM}$ glycine, $2 \mathrm{mM}$ asparagine, and $2.5 \mathrm{mg} / \mathrm{L}$ auxin $(2,4-\mathrm{D})$.

Production of 2-week-old primary callus

Dehulled sterilized seeds were inoculated onto the IM and cultured at $28 \pm 1{ }^{\circ} \mathrm{C}$ in darkness. For callus induction, ten seeds per Petri dish were inoculated and three replicates for each cultivar were maintained. After 2 weeks, the calli were removed from the rice scutellum and used for the SEM and histological analysis.

Production of embryogenic units from primary callus (EUs1)

After 4 weeks of incubation under the same conditions, round embryogenic nodular units $(0.5-1 \mathrm{~mm}$ long) from each cultivar, which were released from the primary embryo scutellumderived callus at the medium interface, were further subcultured onto fresh IM medium for an additional 10 days of incubation. EUs1 were used for SEM observations.

Production of embryogenic units from proliferated 2-week-old cut callus (EUs2)

EUs of BRS Primavera produced as mentioned above were cut into four sections with a scalpel and each piece was transferred onto fresh IM medium for additional 2 weeks of 
incubation for proliferation. The EUs formed were used for SEM analysis.

\section{SEM analysis}

For the morphological observations of the EUs2, 12 calli from BRS Primavera, BRS Bonança, and BRS Caiapó collected from three replications showing an embryogenic appearance were identified by visual observation (color, shape, and size) and selected for analysis. The calli were removed from the Petri dishes, transferred to a fixative solution ( $2 \%$ glutaraldehyde and $2 \%$ paraformaldehyde in $0.1 \mathrm{M}$ cacodylate buffer, pH 7.2) and $3 \%$ sucrose (Karnovsky 1965), and fixed for $24 \mathrm{~h}$. The fixed tissues were then rinsed twice in $0.1 \mathrm{M}$ cacodylate buffer ( $\mathrm{pH}$ 7.2) and maintained in this buffer until the SEM analysis. After dehydration using a graded ethanol series (30, 50, 70, 90, and $100 \%$ per $10 \mathrm{~min}$ ), the samples were critical point-dried in an Autosamdri ${ }^{\circledR}-815$ Series A System dryer (Tousimis Research Corporation, Rockville, MD, USA) with $\mathrm{CO}_{2}$ as the transition fluid. The dried samples were metalized on metal stubs with gold-palladium ions in a Denton Desk V vacuum deposition system (Denton Vacuum, LLC, Moorestown, NJ, USA). The samples were examined using a scanning electron microscope (JSM-6610, JEOL Brasil Instrumentos Científicos Ltda., São Paulo, SP, Brazil) equipped with an energy-dispersive X-ray spectrometer. The same procedure was performed to analyze the EUs1 and EUs2.

\section{Histological analysis}

Resin sections of the callus samples were prepared for histological observations using light microscopy according to the method of Mendoza et al. (1993). Briefly, the samples were dehydrated using a graded alcohol series and embedded in a mixture of absolute ethanol and resin $(1: 1, v / v$; Historesin, Leica, Heidelberg, Germany) for $4 \mathrm{~h}$ and stored for $24 \mathrm{~h}$ in pure Historesin. The resin was polymerized by the addition of hardener and the samples sectioned into 8 - $\mu \mathrm{m}$ slices using a rotatory microtome. The sections were stained with $0.05 \%$ toluidine blue and $0.01 \%$ acid fuchsin for $2 \mathrm{~min}$ and mounted. The microscope tissue sections were photographed using a Leica model DM500 microscope with an ICC50 camera and Leica LAS EZ software.

\section{Agrobacterium-mediated transformation}

One hundred EUs2 of BRS Primavera were infected for 15 min with Agrobacterium strain LBA 4404 harboring the binary vector pCAMBIA1305.1, which contained the hpt II (hygromycin phosphotransferase) hygromycin resistance gene as a selectable marker and the uidA ( $\beta$-glucuronidase activity - GUS) reporter gene, both driven by CaMV35S. The transgene used in this study was the gomesine gene (Swiss-
Prot Data Bank accession no. P82358) from the spider Acanthoscurria gomesiana hemocytes (Silva et al. 2000). A codon-optimized gomesine gene cassette designed for expression in plants (maize ubiquitin promoter-gom-nos terminator) was inserted into the multiple cloning site of pCAMBIA1305.1. The rice transformation procedure was performed as described previously by Sallaud et al. (2003), except by the induction medium.

Twenty calli were assayed for GUS activity by histochemical staining (Jefferson 1987) at 4 days after transfer to the selection medium. The calli that exhibited blue spots were recorded as positive transformants.

To confirm the presence of the transgene in the putatively transformed plants, PCR analysis was performed using genomic DNA from the hygromycin-resistant rice plants, which was extracted as described by Dellaporta et al. (1983) using the 35SP - (forward 5' GGAAGTTCATTTCATTTGGAGAGG 3') and T-NOS-specific primers (reverse 5' GTCCTCATAGA TGACACCGCGC $3^{\prime}$ ). The PCR reaction volume was $20 \mu \mathrm{L}$ with $0.5 \mu \mathrm{L}$ each primer, $1 \mu \mathrm{L}$ template DNA, $2.0 \mu \mathrm{L}$ of $10 \times$ Taq buffer, $0.5 \mu \mathrm{L}$ of $10 \mu \mathrm{M}$ dNTPs, $0.75 \mu \mathrm{L}$ of $50 \mathrm{mM} \mathrm{MgCl}_{2}$, and $0.3 \mu \mathrm{L}$ recombinant Taq DNA polymerase (Invitrogen ${ }^{\mathrm{TM}}$ ). The PCR amplification program was as follows: denaturation at $95^{\circ} \mathrm{C}$ for $3 \mathrm{~min} ; 35$ cycles of $94^{\circ} \mathrm{C}$ for $30 \mathrm{~s}, 55^{\circ} \mathrm{C}$ for $30 \mathrm{~s}$, and $72{ }^{\circ} \mathrm{C}$ for $1 \mathrm{~min}$; and extension at $72{ }^{\circ} \mathrm{C}$ for $5 \mathrm{~min}$. The PCR products were analyzed using $1 \%$ agarose gel electrophoresis.

The regeneration frequency (in percent) was calculated based on the number of cut calli that regenerated shoots divided by the number of calli inoculated with Agrobacterium $(\times 100 \%)$.

\section{Statistical analysis}

Statistical comparisons were performed using the paired twotailed Student's $t$ test. All values are reported as the mean \pm $\mathrm{SD}$, with significance assumed at $p<0.05$.

\section{Results}

Two-week-old calli

After 2 weeks in the induction medium, compact creamcolored calli were obtained from mature embryos (Fig. 1a) and separated from the scutellum for SEM and histological analysis. There were no visual differences among the calli from each of the three cultivars, which all showed a round and yellowish callus. The calli from each cultivar were first used for SEM analysis. A typical embryogenic globular, compact structure containing tightly packed cells was observed for BRS Bonança (Fig. 1b) and BRS Primavera. In contrast, the calli of BRS Caiapó consisted of unorganized, long tubular cells (Fig. 1c, d). 
Fig. 1 Callus development and SEM images of 2-week-old callus. a, b BRS Bonança. c, d BRS Caiapó. e, $\mathbf{f}$ ECMSN of BRS Bonança. g, h Trichomes: BRS Primavera (g) and BRS Caiapó (h). a Callus (cal) developed from scutellum with a visible coleptile $(\mathrm{col})$ and seed remnants. b Globular structures (black arrows) on the compact callus. Parenchymal cells of callus composed of small, few cellular clusters (c) show fibrillar structures (d) (white

arrowheads). Callus covered with membranous structure (white asterisks) (e) show transition from membranous to fibrillar structures (f). Black asterisks indicate fibrils forming a thick band. Numerous trichomes visible on the callus; note the long cells (black arrowheads) that produce the trichomes $(\mathbf{g}, \mathbf{h})$. Bar: $1 \mathrm{~mm}(\mathbf{a}) ; 100 \mu \mathrm{m}(\mathbf{b}, \mathbf{c}, \mathbf{f}$, g, h); $20 \mu \mathrm{m}(\mathbf{d}, \mathbf{e})$
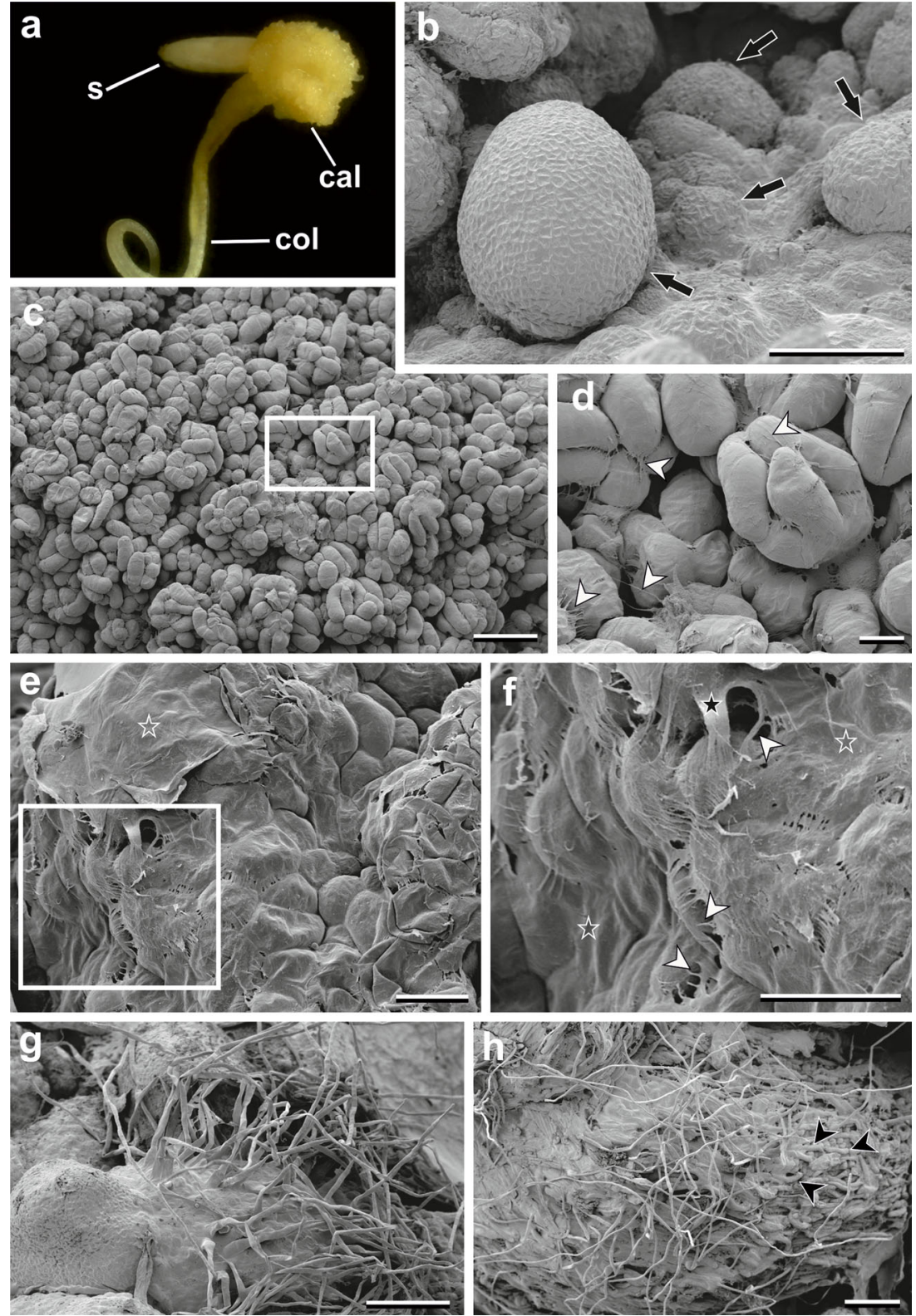

SEM revealed the presence of a discontinuous amorphous layer outside of the outer cell wall on the callus surface, as shown in the calli of BRS Primavera, BRS Bonança (Fig. 1e, f), and BRS Caiapó. This material covered the surfaces of the cells of the embryogenic and non-embryogenic calli to form a network-like structure and bridges connecting neighboring cells. Additionally, trichomes were observed on the surfaces of both embryogenic and non-embryogenic calli (Fig. 1g, h).

The 2-week-old calli were also used for histological analysis. The scutellum-derived primary callus consisted of parenchymatic cells (Fig. 2a-d). The external layer of the callus was composed of small, isodiametric, densely stained meristematic cells which were organized into small units (Fig. 2a, d) or large protuberances (Fig. 2c). The small units were especially abundant in the peripheral regions of the calli (Fig. 2b).
Additionally, part of the callus was composed of a mixture of different types of callus tissue (Fig. 2e). Within the large protuberances, cambial-like tissues with cells having a regular organization (Fig. 2c) were observed. The surfaces of some protuberances were covered with epidermis-like tissue (Fig. 2f).

\section{EUs from primary calli (EUs1)}

Three to 4 weeks after inoculation, the primary scutellar calli released at the medium interface globular structures of 0.5 - to $1-\mathrm{cm}$ round, compact, and prolific calli. BRS Primavera and BRS Bonança (Fig. 3a) released EUs easier than the EUs of BRS Caiapó (Fig. 3b). The EUs (0.5-1 mm long) released from the primary embryo scutellum-derived callus were transferred onto fresh IM medium and incubated for an additional 
Fig. 2 Histological sections of 2-week-old calli of the three rice cultivars. BRS Bonança $(\mathbf{a}-\mathbf{c})$, BRS Primavera (d), and BRS Caiapó $(\mathbf{e}, \mathbf{f})$ stained with toluidine blue, except (c), which was stained with fuchsin. Primary callus $(p c)$ and the formation of embryogenic callus units (em) and nonembryogenic callus (nem) are visible (a, b). Large callus domain/ protuberances (white arrows) (c) or small but numerous embryogenic callus units (black arrows) (d). c, $\mathbf{e}$ Note the cambial-like tissue (cam) inside the large protuberances. f Epidermis-like tissue $(e p)$ on the surface of some protuberances. Bar: $500 \mu \mathrm{m}(\mathbf{a}-\mathbf{f})$
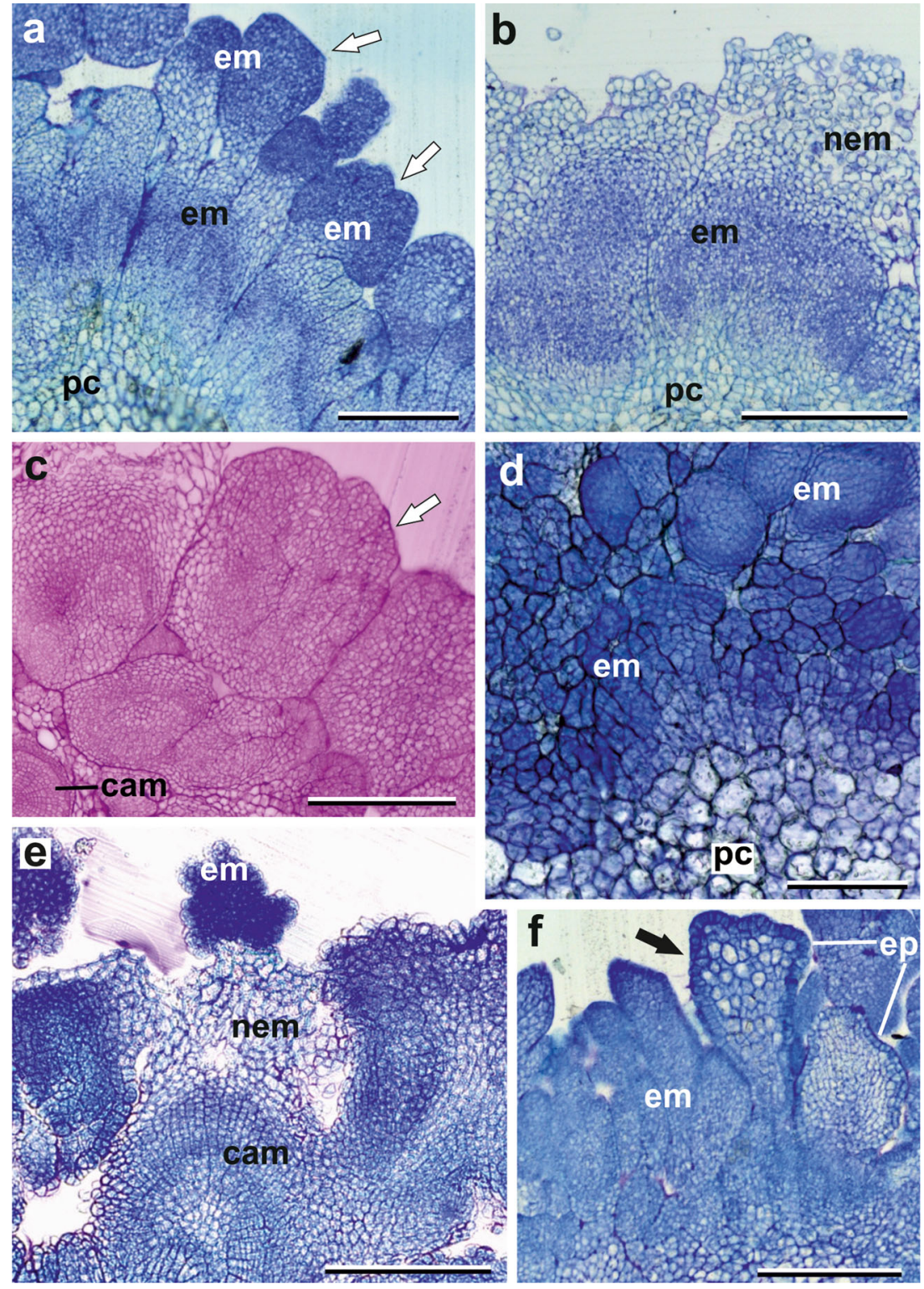

10 days. After this period, two types of callus were visually observed: those with a light yellow, compact, and smooth appearance and those having a yellowish surface and granular appearance. The first type of callus mass was mainly observed in BRS Primavera and BRS Bonança, whereas the second type was mainly observed in BRS Caiapó. The extracellular matrix surface network (ECMSN) and fibrils were also observed in the embryogenic and nonembryogenic calli, as exemplified in the photograph of BRS Bonança (Fig. 3c). The characteristics of the embryogenic callus were preserved in the EUs1 from BRS Bonança and BRS Primavera, which showed a globular, compact structure that contained tightly packed cells. The EUs1 of BRS Caiapó also maintained the pattern of a nonembryogenic callus, such as the presence of elongated, unorganized cells (Fig. 3d).
Embryogenic units from proliferated 2-week-old cut callus (EUs2)

We investigated 126 two-week-old calli from BRS Primavera, from three replications, which were cut into three to four pieces (depending on the callus size). They produced a total of 436 pieces, which were subcultured in Petri dishes with fresh IM medium and proliferated into more than 850 calli. Overall, two different types of callus were produced: embryogenic (compact, yellowish, and large size) and nonembryogenic (friable, translucent, and slimy) based on visual observation. We selected 250 embryogenic calli and used 15 for the SEM analysis. The proliferation response of these calli was as rapid as the callus production being observed within 1 week of culture. Multiple or clusters of calli could be observed around the swollen piece of callus (Fig. 3e). The 

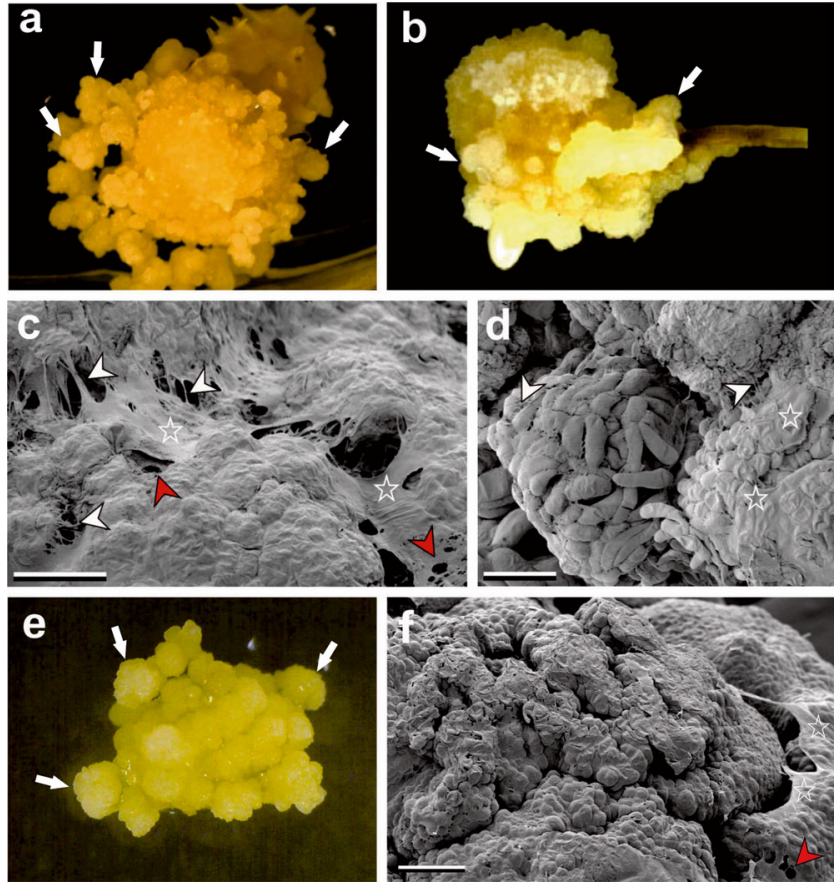

Fig. 3 Callus development and SEM images of the EUs1 (a-d) and EUs2 (e, f) of BRS Bonança (a, c), BRS Caiapó $(\mathbf{b}, \mathbf{d})$, and Primavera $(\mathbf{e}, \mathbf{f})$. a, b, e, Globular/clump structures of callus are visible. $\mathbf{c}, \mathbf{d}, \mathbf{f}$, Membranous (asterisks) and fibrillar (arrowheads) aspects of ECM. Note the fibrils (white arrowheads) and membranous structures (white asterisks) with holes (red arrowheads) covering the callus surface. Bar: $50 \mu \mathrm{m}(\mathbf{b}) ; 100 \mu \mathrm{m}(\mathbf{d}, \mathbf{f})$

embryogenic calli were collected and subcultured for 7 days and then used for the SEM analysis.

As observed in the EUs from primary calli, the proliferating callus showed an embryogenic globular and compact structure for BRS Primavera (Fig. 3f). The presence of the ECMSN was also maintained. These features suggested that callus proliferated from cut primary callus is suitable for transformation experiments.

Transgenic plants detected by histochemical staining and PCR test

Because the Eus2 grew vigorously and showed embryogenic potential, the BRS Primavera calli were chosen for transformation experiments. The success of transformation was assessed based on the percentage of calli with blue spots, signifying transient expression of the uidA gene. GUS histochemical staining was performed 4 days after transfer to the selection medium. Calli of the same size, color, and embryogenic status were chosen for this experiment. Of the 20 calli sampled from cut proliferated calli, $11(55 \%)$ showed blue spots (Fig. 4a-c).

After co-cultivation, 100 calli were transferred into the selection medium (Sallaud et al. 2003) containing $50 \mathrm{mg} / \mathrm{L}$ hygromycin and subsequently transferred to the regeneration medium (Sallaud et al. 2003). After obtaining a large number of regenerated shoots (Fig. 4d, e), they were subsequently shifted to the rooting medium.

To evaluate the insertion of the transgene into the plant genome, DNA was extracted from the $T_{1}$ regeneration plant leaves and analyzed using PCR. The presence of the 450-bp gom fragment (Fig. 4f) in the plant genome was confirmed in $85 \%$ of the regenerated transformed plants. The inserted gene was lacking in non-transgenic BRS Primavera.

The EUs2 exhibited regeneration frequencies of 95 and $62 \%$ in the non-transformed and transformed hygromycinresistant cell lines, respectively (Fig. 5).

\section{Discussion}

Callus induction is considered to be of great importance for obtaining well-formed somatic embryos and for the subsequent stages of development, i.e., maturation and conversion into plants. Herein, histological analysis and SEM were used to analyze primary callus and EUs during early rice callogenesis in the Brazilian rice cultivars BRS Primavera, BRS Bonança, and BRS Caiapó.

Morphological variations between embryogenic (BRS Bonança and BRS Primavera) and non-embryogenic calli (BRS Bonança) were observed, which have also been reported for certain rice cultivars based on the external (Abe and Futsuhara 1985) and internal morphology of the callus (Mendoza and Futsuhara 1992; Sangduen and Klamsomboon 2001).

Formed via a somatic embryogenesis pattern, embryos are developed from friable embryogenic calli derived from the rice scutellum (Molina et al. 2002; Quiroz-Figueroa et al. 2006). Somatic embryo quality is essential for obtaining high somatic embryo conversion rates and can be improved by the optimization of the induction medium parameters, such as the components and the type and concentration of plant growth regulators. Frequently, a culture medium that performs well for one genotype does not work well for others, and thus, efforts are needed on a genotype-by-genotype basis (Hiei and Komari 2008). A different induction medium might increase the callus quality of BRS Caiapó because embryogenic callus induction is dependent on the interaction between the genotypes and culture conditions (Visarada et al. 2002). This outcome is exemplified by the rice cultivars Swarma and Mahsuri, which showed 49 and $71 \%$ higher callus induction in a modified (Murashige and Skoog 1962) MS medium than the basal salt MS, respectively (Pravin et al. 2011).

SEM analysis revealed also the presence of the extracellular matrix surface network (ECMSN) in all three cultivars, which consists of a fibrillar network (Samaj et al. 1995). A similar structure has also been reported in other plant species such as Zea mays (Samaj et al. 1999), Cocos nucifera (Verdeil et al. 2001), Brassica napus (Namasivayam et al. 2006), Triticum aestivum (Konieczny et al. 2005; Pilarska et al. 
Fig. 4 Expression of GUS and detection of transgene insertion in the transgenic lines. a-c GUS expression in leaves. $\mathbf{d}, \mathbf{e}$ Regeneration of hygromycinresistant calli from EUs2. f PCR amplification of the transgene from genomic DNA extracted from young leaves of selected $\mathrm{T} 1$ plants cultivated in a greenhouse (lane 1: non-transgenic)
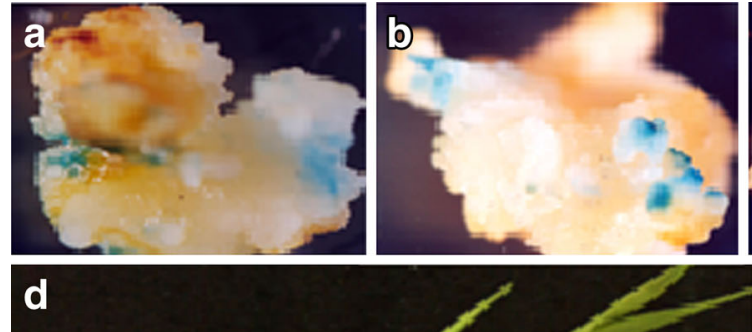
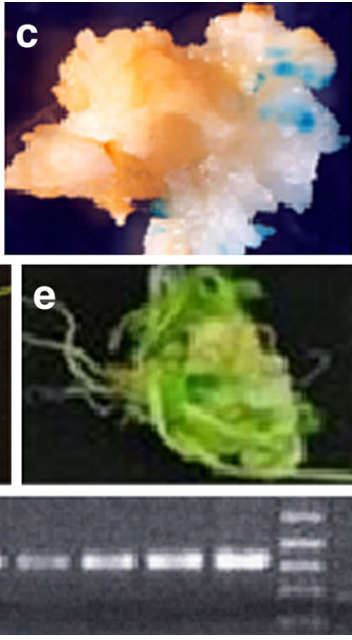

2007), Actinidia deliciosa (Popielarska-Konieczna et al. 2010), Centella asiatica (Lai et al. 2011), and Elaeis guineensis (Yusoff et al. 2012). The non-cellular nature of the ECMSN was revealed by Verdeil et al. (2001) and Konieczny et al. (2005) using transmission electron microscopy.

The ECMSN can also be a stress response to in vitro conditions during callus preparation for SEM examination or may be observed as a result of artifacts caused by chemical fixation, dehydration, and critical-point drying (Kachar et al. 1990; McCann et al. 1990). This feature was also verified by Konieczny et al. (2005) who lyophilized wheat calli after freezing in liquid nitrogen prior to SEM observation. This technique revealed the presence of a coherent layer of secretions over the cell surface with wide bridge-like strips between adjacent cells. However, the ECMSN was not observed on the large parenchymatous cells of calli in conventionally prepared material.

The ECSMN is considered to play a fundamental role in the reception and transduction of signals associated with positional information, recognition, cell fate determination, and plant development as well as in morphogenic processes (Popielarska-Konieczna et al. 2010). In several plants cultured in vitro, the induction of morphogenesis is linked to the appearance of fibrillar material covering the surface (Konieczny et al. 2005). The presence of this fibrillar coat, i.e., the ECMSN, in the developing callus of oil palm was suggested to be an indicator that the cells would later acquire the ability to form embryogenic tissue (Yusoff et al. 2012).

The ECMSN is also considered to be a marker of embryogenic cells (Samaj et al. 1999) for C. nucifera, Z. mays, Drosera, and Papaver. However, in our study, the ECMSN was observed in both the embryogenic and non-embryogenic calli, possibly because of the early stage of callus formation. In our study, both the embryogenic and non-embryogenic calli showed remnant or early ECM formation on the surfaces of the cells (Fig. 2d, e), which is in contrast to the results of
Dubois et al. (1991), Ovečka et al. (1998), Chapman et al. (2000), Namasivayam et al. (2006), Popielarska et al. (2006), and Lai et al. (2011) who reported that an ECM layer was absent from the non-embryogenic cells of Cichorium intybus, Papaver somniferum, B. napus, A. deliciosa, and C. asiatica . This discrepancy may have resulted from genotypic variation or the early stage of the calli used in our study.

Additionally, trichomes were observed on the surfaces of both embryogenic and non-embryogenic calli. Trichomes have thus far not been reported in rice undergoing callus formation. In general, trichomes are visible during rice callus regeneration (Brisibe et al. 1992) and rooting (Nakamura and Maeda 1989). The presence of trichomes is particularly suggestive of the capability of surfaces to readily form leafy primordial cells. As trichomes were present in only $1 \%$ of all calli, we suggest that they were in a more advanced stage of development than the others.

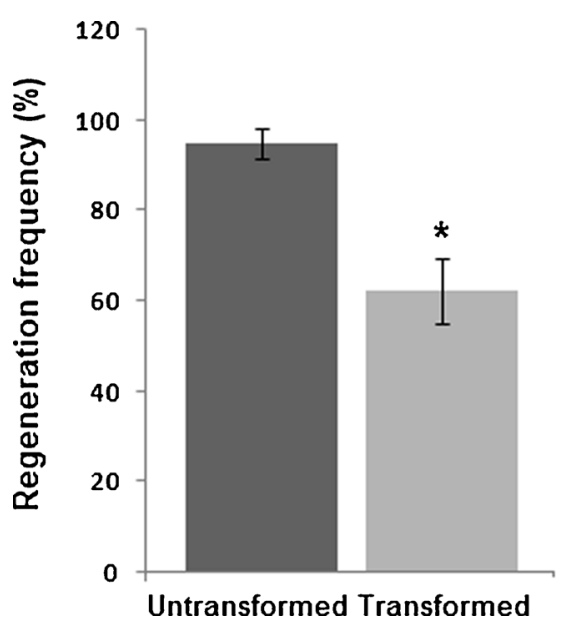

Fig. 5 Regeneration and transformation frequency of untransformed (93\%) and transformed rice lines (62\%) using either LBA4404 carrying gom gene. *Significantly different from the untransformed calli $(P<0.05$ by paired twotailed Student's $t$ test) 
The 2-week-old calli were also used for histological analysis. Generally, the SEM images corresponded to the histological sections. The globular, compact structures detected in BRS Primavera and BRS Bonança cultivars were visible as large protuberances or small units composed of meristematic cells. Structures from the peripheral part of the callus of $\mathrm{cv}$. BRS Caiapó had a finger-like shape and a higher abundance of parenchymatic cells.

Parenchymatic cells in the interior part and meristem cells in the peripheral part of rice callus have been reported (Alfonso-Rubi et al. 1999; Vega et al. 2009; Narciso and Hattori 2010). The occurrence of epidermis- and cambiallike tissues may indicate that differentiation processes are in progress. An epidermis-like layer has been observed in callus protuberances during the induction of organogenesis (Popielarska-Konieczna et al. 2011). Additionally, meristematic cells forming cambial-like regions inside the callus mass are often connected by an organized vascular system.

The comparative SEM analysis of EUs from primary calli of the three cultivars revealed a contrasting morphological organization at a development stage considered suitable for transformation, as observed in the 2-week-old calli. The characteristics of the embryogenic callus were preserved in the EUs from BRS Bonança and BRS Primavera, which showed a globular, compact structure that contained tightly packed cells, whereas the non-embryogenic type was mainly observed in BRS Caiapó. Again, the three cultivars showed also the presence of the ECMSN. The permanence of these structures is particularly important because the presence of the ECMSN during somatic embryogenesis is also associated with the acquisition of embryogenic competence (Namasivayam 2007). In fact, EUs from primary calli are often used as the starting material in transformation experiments.

It was important to investigate whether proliferated EUs2 are suitable for rice transformation. The quality of the rice calli is considered a key factor for success in transformation (Lin and Zhang 2005). Hiei and Komari (2008) reported the use of cut callus from immature embryo for direct Agrobacterium tumefasciens transformation. In our study, the presence of the ECMSN and morphological characteristics derived from cut 2-week-old callus was also maintained for all three rice cultivars. These features suggest that callus proliferated from cut primary callus is suitable for direct transformation experiments.

Notably, no rice cultivar is capable of inducing only embryogenic calli. Calli induced from mature embryos differ considerably in their morphology and may be nodular, spherical, flat, amorphous, rhizogenic, translucent, or invaginated. For consistency, the callus may be compact, hard, loose, friable, or dissociated. In rice, seven different types of calli are induced from mature seeds (Visarada et al. 2002), and they differ in their morphological characteristic sand potential for plant regeneration (Nabors et al. 1983). The number, color, size, shape, and appearance time of the induced embryogenic calli vary among rice cultivars depending on the type of basal medium (Lee et al. 2002), the quality of the seeds, and the genotype of the rice. For example, the rice genotype Lx297 was found to be more responsive to MS medium than IR-64 and V19, which yielded $82.50,18.77$, and $6.4 \%$ of callus, respectively (Khatun et al. 2003). Thus, many of the recent studies reporting improved protocols have focused on medium optimization and the handing of the callus using various genotypes to select the best to induce embryogenic calli.

The response of seeds to callus induction depends greatly on the rice cultivars. For certain japonica cultivars, such as Nipponbare, the preparation of a highly transformable calli is straightforward and highly reproducible (Hiei and Komari 2008).

In a previous work (Bevitori, unpublished), BRS Primavera, BRS Bonança, and BRS Caiapó presented 84, 72, and $33 \%$ callus induction. However, although it is considered a non-embryogenic cultivar, BRS Caiapó produced some embryogenic calli. Therefore, the SEM analysis of BRS Caiapó also revealed some features common to embryogenic calli, such as the EMCSN, which is suggested to be an indicator that the cells would later acquire the ability to form embryogenic tissue (Yusoff et al. 2012). The histological analysis also revealed multiple finger-like embryogenic units, which is a feature of embryogenic calli.

Independent of the frequency of the different types of callus, the histological analysis suggested that all cultivars used in the experiments have morphogenic potential. This finding suggests that the modification in the medium may help the embryogenic features of BRS Caiapó. More detailed studies should be developed aiming to obtain BRS Caiapó somatic embryos of higher quality, which can be efficiently converted into plants. The somatic embryo quality can be improved with the optimization of parameters such as the type and concentration of plant growth regulators, the time in induction medium, and the maturation treatments.

To verify the ability of the EUs2 for Agrobacterium -transformation, we used BRS Primavera calli, which showed embryogenic potential in this experiment. Expression of GUS was detected in $55 \%$ of the calli. The presence of the 450-bp gom fragment in the plant genome was confirmed by PCR in $85 \%$ of the regenerated transformed plants, which exhibited regeneration/transformation frequencies of 95 and $62 \%$ in the non-transformed and transformed hygromycin-resistant cell lines, respectively (Fig. 5). The reported efficiencies of Agrobacterium-mediated transformation in rice callus tissue typically range from 10 to $50 \%$ (Hiei et al. 1994; Dong et al. 1996; Rashid et al. 2001; Datta et al. 2001; Nakagawa et al. 2000), and these efficiencies are considered satisfactory for introducing genes of interest into rice. Sallaud et al. (2003) reported that the regeneration frequency for non-transformed calli ranged from 75 to $98 \%$ when using EUs from the primary calli. 
In this study, we reported the first SEM analysis of EUs that showed typical embryogenic structures from EUs derived from either primary or 2-week-old cut calli from Brazilian rice cultivars. Additionally, we show that EUs2 are suitable for plant transformation. These results might be useful for any rice cultivar and could lead to new ways of manipulating rice callus by cutting 2 -week-old callus. This can improve the acquisition of a large number of embryogenic calli from a smaller number of calli in a short period of time while maintaining the embryogenic features and the consequent transformation ability.

Acknowledgments We thank the Universidade Federal de Goiás for the use of the LabMIC and the Laboratório de Morfologia e Anatomia de Plantas. This work was funded by Embrapa and the Conselho Nacional de Desenvolvimento Científico e Tecnológico (CNPq)

Conflict of interest The authors declare that they have no conflict of interest.

\section{References}

Abe T, Futsuhara Y (1985) Efficient plant regeneration from protoplast through somatic embryogenesis. Biol Technol 4:1087-1090

Alfonso-Rubi J, Carbonero P, Diaz I (1999) Parameters influencing the regeneration capacity of calluses derived from mature indica and japonica rice seeds after microprojectile bombardment. Euphytica 107:115-122

Brisibe EA, Miyake H, Taniguchi T et al (1992) Callus formation and scanning electron microscopy of plantlet regeneration in African rice (Oryza glaberrima Steud). Plant Sci 83:217-224

Chapman A, Blervacq AS, Hendrix T et al (2000) Cell wall differentiation during early somatic embryogenesis in plants. II. Ultrastructural study and pectin immunolocalization on chicory embryos. Can J Bot 78:824-831

Chen TH, Lam L, Chen SC (1985) Somatic embryogenesis and plant regeneration from cultured young inflorescences of Oryza sativa $\mathrm{L}$. (rice). Plant Cell Tissue Org Cult 4:51-54

Datta K, Tu JM, Oliva N et al (2001) Enhanced resistance to sheath blight by constitutive expression of infection-related rice chitinase in transgenic elite indica rice cultivars. Plant Sci 160:405-414

Dellaporta SL, Wood J, Hicks JB (1983) A plant DNA minipreparation: version II. Plant Mol Biol Report 4:19-21

Dong J, Teng W, Buchholz WG et al (1996) Agrobacterium-mediated transformation of javanica rice. Mol Breed 2:267-276

Dubois T, Guedira M, Vasseur J (1991) Direct somatic embryogenesis in leaves of Cichorium. A histological and SEM study of early stages. Protoplasma 162:120-127

Fehér A, Pasternak T, Otvos K et al (2002) Induction of embryogenic competence in somatic plant cells: a review. Biologia 57:5-12

Hiei Y, Komari T (2008) Agrobacterium-mediated transformation of rice using immature embryos or calli induced from mature seed. Nat Protoc 3:824-834

Hiei Y, Ohta S, Komari T et al (1994) Efficient transformation of rice (Oryza sativa L.) mediated by Agrobacterium and sequence analysis of the boundaries of the T-DNA. Plant J 6:271-282

Hiei Y, Ohta S, Komari T et al (1997) Transformation of rice mediated by Agrobacterium tumefaciens. Plant Mol Biol 35:205-218

Jefferson RA (1987) Assaying chimeric genes in plants: the Gus gene fusion system. Plant Mol Biol Report 5:387-405
Jones TJ, Rost TL (1989) The developmental anatomy and ultrastructural of somatic embryos from rice (Oryza sativa L.) scutellum epithelial cells. Bot Gaz 150:41-49

Kachar B, Parakkal M, Frex J (1990) Structural basis form mechanical transduction in the frog vestibular sensory apparatus: the otholitic membrane. Hear Res 45:179-190

Karnovsky MJ (1965) A formaldehyde-glutaraldehyde fixative of high osmolarity for use in electron microscopy. J Cell Biol 27:137-138

Khatun MM, Ali MH, Desamero NV (2003) Effect of genotype and culture media on callus formation and plant regeneration from mature seed scutella culture in rice. Plant Tissue Cult 13:99-107

Konieczny R, Bohdanowicz J, Czaplicki AZ et al (2005) Extracellular matrix surface network during plant regeneration in wheat anther culture. Plant Cell Tissue Org Cult 83:201-208

Lai KS, Yusoff K, Maziah M (2011) Extracellular matrix as the early structural marker for Centella asiatica embryogenic tissues. Biol Plant 55:549-553

Lee KS, Jeon HS, Kim MY (2002) Optimization of a mature embryobased in vitro culture system for high-frequency somatic embryogenic callus induction and plant regeneration from japonica rice cultivars. Plant Cell Tissue Org Cult 71:237-244

Lin YJ, Zhang Q (2005) Optimizing the tissue culture conditions for high efficiency transformation of indica rice. Plant Cell Rep 23:540-547

McCann MC, Wells B, Roberts K (1990) Direct visualization of crosslinks in the primary plant cell wall. J Cell Sci 96:323-334

Mendoza AB, Futsuhara Y (1992) Histological observations on plant regeneration in rice (Oryza sativa L.) calli. Jpn J Breed 42:33-41

Mendoza AB, Hattori K, Nishimura T et al (1993) Histological and scanning electron microscopic observations on plant regeneration in mungbean cotyledon (Vigna radiata (L.) Wilczek) cultured in vitro. Plant Cell Tissue Org Cult 32:137-143

Molina D, Aponte M, Cortina H (2002) The effect of genotype and explant age on somatic embryogenesis of coffee. Plant Cell Tissue Org Cult 71:117-123

Murashige T, Skoog F (1962) A revised medium for rapid growth and bioassays with tobacco tissue culture. Physiol Plant 15:437-497

Nabors MW, Heyser JW, Dykes TA et al (1983) Long-duration, highfrequency plant regeneration from cereal tissue cultures. Planta 157: 385-391

Nakagawa Y, Machida C, Machida Y et al (2000) Frequency and pattern of transposition of the maize transposable element Ds in transgenic rice plants. Plant Cell Physiol 41:733-742

Nakamura T, Maeda E (1989) A scanning electron microscope study on japonica type rice callus cultures, with emphasis on plantlet initiation. Jpn J Crop Sci 58:395-403

Namasivayam P (2007) Acquisition of embryogenic competence during somatic embryogenesis. Plant Cell Tissue Org Cult 90:1-8

Namasivayam P, Skepper J, Hanke D (2006) Identification of a potential structural marker for embryogenic competency in the Brassica napus ssp. Oleifera embryogenic tissue. Plant Cell Rep 25:887-895

Narciso JO, Hattori K (2010) Genotypic differences in morphology and ultrastructures of callus derived from selected rice varieties. Philipp Sci Lett 3:59-65

Nishimura S, Maeda E (1977) Histological studies of callus induction in rice seed. Jpn J Crop Sci 46:275-285

Ovečka M, Bobák M, Blehová A et al (1998) Papaver somniferum regeneration by somatic embryogenesis and shoot organogenesis. Biol Plant 40:321-328

Pescador R, Araújo PS, Maas CH et al (2000) Biotecnologia de Piper hispidinervium - pimenta longa. Biotecnol Cienc Desenvolv 3:19-23

Pilarska M, Czaplicki A, Konieczny R (2007) Patterns of pectin epitope expression during shoot and root regeneration in androgenic cultures of two wheat cultivars. Acta Biol Cracov Bot 49:69-72

Popielarska M, Ślesak H, Goralski G (2006) Histological and SEM studies on organogenesis in endosperm-derived callus of kiwifruit (Actinidia deliciosa cv. hayward). Acta Biol Cracov Bot 48:97-104 
Popielarska-Konieczna M, Bohdanowicz J, Starnawska E (2010) Extracellular matrix of plant callus tissue visualized by ESEM and SEM. Protoplasma 247:121-125

Popielarska-Konieczna M, Kozieradzka-Kiszkurno M, Bohdanowicz J (2011) Cutin plays a role in differentiation of endosperm-derived callus of kiwifruit. Plant Cell Rep 30:2143-2152

Pravin VJ, Dudhare MS, Saluja T, Sarawgi C (2011) Assessment of critical factors influencing callus induction, in vitro regeneration and selection of bombarded indica rice genotypes. J Agric Biotechnol Sustain Dev 3:44-59

Quiroz-Figueroa FR, Rojas-Herrera R, Galaz-Avalos RM et al (2006) Embryo production through somatic embryogenesis can be used to study cell differentiation in plants. Plant Cell Tissue Org Cult 86: 285-301

Rashid H, Bokhari SYA, Quraishi A (2001) Callus induction, regeneration and hygromycin selection of rice (Super Basmati). Online J Biol Sci 1:1145-1146

Saika H, Toki S (2010) Mature seed-derived callus of the model indica rice variety Kasalath is highly competent in Agrobacterium-mediated transformation. Plant Cell Rep 29:1351-1364

Sallaud C, Meynard D, Van Boxtel J et al (2003) Highly efficient production and characterization of T-DNA plants for rice (Oryza sativa L.) functional genomics. Theor Appl Genet 106:1396-1408

Samaj MB, Bobak M, Blehova A et al (1995) Developmental SEM observations on an extracellular matrix in embryogenic calli of Drosera rotundifolia and Zea mays. Protoplasma $186: 45-49$
Samaj J, Baluška F, Bobák M et al (1999) Extracellular matrix surface network of embryogenic units of friable maize callus contains arabinogalactan-proteins recognized by monoclonal antibody JIM4. Plant Cell Rep 18:369-374

Sangduen N, Klamsomboon P (2001) Histological and scanning electron observations on embryogenic and non-embryogenic calli of aromatic Thai rice (Oryza sativa L. cv. Khao Daw Mali 105). Kasetsart J (Nat Sci) 35:427-432

Silva PI Jr, Daffre S, Bulet P (2000) Isolation and characterization of gomesin, an 18-residue cysteine-rich defense peptide from the spider Acanthoscurria gomesiana hemocytes with sequence similarities to horseshoe crab antimicrobial peptides of the tachyplesin family. J Biol Chem 275:33464-33470

Vega R, Vásquez N, Espinoza AM et al (2009) Histology of somatic embryogenesis in rice (Oryza sativa cv. 5272). Rev Biol Trop 57: $141-150$

Verdeil JL, Hocher V, Huet C et al (2001) Ultrastructural changes in coconut calli associated with the acquisition of embryogenic competence. Ann Bot 88:9-18

Visarada KBRS, Sailaja M, Sarma NP (2002) Effect of callus induction media on morphology of embryogenic calli in rice genotypes. Biol Plant 45:495-502

Williams EG, Maheswaran G (1986) Somatic embryogenesis: factors influencing coordinated behaviour of cells as an embryogenic group. Ann Bot 57:443-462

Yusoff NFM, Alwee SSRS, Abdullah MO (2012) A time course anatomical analysis of callogenesis from young leaf explants of oil palm (Elaeis guineensis Jacq.). J Oil Palm Res 24:1330-1341 